\title{
Response of two marine bacterial isolates to high $\mathrm{CO}_{2}$ concentration
}

\author{
Eva Teira ${ }^{1, *}$, Ana Fernández ${ }^{1}$, Xosé Antón Álvarez-Salgado ${ }^{2}$, \\ Enma Elena García-Martín ${ }^{1}$, Pablo Serret ${ }^{1}{ }^{1}$, Cristina Sobrino ${ }^{1}$
}

\author{
${ }^{1}$ Departamento Ecoloxía e Bioloxía Animal, Universidade de Vigo, Campus Lagoas-Marcosende 36310 Vigo, Spain \\ ${ }^{2}$ Consejo Superior de Investigaciones Científicas (CSIC), Instituto de Investigacións Mariñas, Eduardo Cabello 6, \\ 36208 Vigo, Spain
}

\begin{abstract}
Experimental results related to the effects of ocean acidification on planktonic marine microbes are still rather inconsistent and occasionally contradictory. Moreover, laboratory or field experiments that address the effects of changes in $\mathrm{CO}_{2}$ concentrations on heterotrophic microbes are very scarce, despite the major role of these organisms in the marine carbon cycle. We tested the direct effect of an elevated $\mathrm{CO}_{2}$ concentration $(1000 \mathrm{ppmv})$ on the biomass and metabolic rates (leucine incorporation, $\mathrm{CO}_{2}$ fixation and respiration) of 2 isolates belonging to 2 relevant marine bacterial families, Rhodobacteraceae (strain MED165) and Flavobacteriaceae (strain MED217). Our results demonstrate that, contrary to some expectations, high $p \mathrm{CO}_{2}$ did not negatively affect bacterial growth but increased growth efficiency in the case of MED217. The elevated partial pressure of $\mathrm{CO}_{2}\left(p \mathrm{CO}_{2}\right)$ caused, in both cases, higher rates of $\mathrm{CO}_{2}$ fixation in the dissolved fraction and, in the case of MED217, lower respiration rates. Both responses would tend to increase the $\mathrm{pH}$ of seawater acting as a negative feedback between elevated atmospheric $\mathrm{CO}_{2}$ concentrations and ocean acidification.
\end{abstract}

KEY WORDS: Bacterial metabolism $\cdot$ Flavobacteriaceae $\cdot$ Ocean acidification $\cdot$ Rhodobacteraceae - Resale or republication not permitted without written consent of the publisher

\section{INTRODUCTION}

In the last $200 \mathrm{yr}$, the oceans have absorbed about $50 \%$ of the anthropogenic $\mathrm{CO}_{2}$ (Sabine et al. 2004), which has resulted in a reduction of surface seawater $\mathrm{pH}$ of 0.1 units (Royal Society 2005). Caldeira \& Wickett (2003) estimate that surface ocean seawater $\mathrm{pH}$ will decrease by 0.7 units over the next $200 \mathrm{yr}$.

Ocean acidification could have severe consequences for marine biota, including both calcifying and non-calcifying organisms (Raven et al. 2005, Fabry et al. 2008), but there is no solid evidence about how the different organisms will react to the coupled $p \mathrm{CO}_{2}-\mathrm{pH}$ change (Hendriks et al. 2010). In the case of marine microbes, the experimental results are inconsistent and occasionally contradictory (Joint et al. 2011, Liu et al. 2010).
Compared to experiments on phytoplankton, far fewer laboratory or field experiments have assessed the effects of changes in $\mathrm{CO}_{2}$ concentrations on heterotrophic microbes (Joint et al. 2011), despite these playing a major role in the marine carbon cycle, mineralizing organic carbon in the oceans to $\mathrm{CO}_{2}$ (del Giorgio \& Williams 2005). A few mesocosm experiments have tested the effect of high $\mathrm{CO}_{2}$ concentrations on the abundance and/or production of natural bacterioplankton populations (Rochelle-Newall et al. 2004, Grossart et al. 2006, Allgaier et al. 2008). These studies have found either no or indirect (linked to phytoplankton dynamics) effect of elevated partial pressure of $\mathrm{CO}_{2}\left(p \mathrm{CO}_{2}\right)$ on bacterial production (BP). Only a few studies have demonstrated a direct effect of $\mathrm{CO}_{2}$ on natural prokaryotic plankton from the deep ocean (Coffin et al. 2004, Yamada et al. 2010) or 
on marine bacterial isolates (Takeuchi et al. 1997, Labare et al. 2010). The latter studies found a decrease in the production and growth rates at $\mathrm{pH}<$ 7 - values far from the usual $\mathrm{pH}$ observed in ocean waters under present or future scenarios of elevated $p \mathrm{CO}_{2}$.

Most microorganisms, particularly heterotrophic bacteria, are able to assimilate $\mathrm{CO}_{2}$ as part of their metabolism through anaplerotic reactions (Roslev et al. 2004). Although light-independent or dark $\mathrm{CO}_{2}$ assimilation has been usually assumed to be insignificant in oxygenated marine waters, a recent work by Alonso-Sáez et al. (2010) suggests that the global relevance of this process could have been underestimated. Those results show for the first time that high ambient $\mathrm{CO}_{2}$ concentrations could stimulate $\mathrm{CO}_{2}$ fixation rates by increasing the $\mathrm{CO}_{2}$ flux into the cells.

A comprehensive understanding of the effect of elevated $\mathrm{CO}_{2}$ concentration on carbon cycling in the ocean requires the analysis of both production and respiration rates to provide a total carbon budget. However, to the best of our knowledge none of the published studies have simultaneously addressed the effect of $\mathrm{CO}_{2}$ on $\mathrm{BP}$ and respiration, which are essential variables for bacterial growth efficiency (BGE) calculations. Allgaier et al. (2008) did find changes in bacterial taxonomic composition in response to high $\mathrm{CO}_{2}$ concentrations, which suggest that the effects of elevated $p \mathrm{CO}_{2}$ are likely to vary among species. Therefore, the aim of the present study was to test the direct effect of elevated $\mathrm{CO}_{2}$ concentrations (1000 ppmv) on the biomass and metabolic rates (leucine incorporation, $\mathrm{CO}_{2}$ fixation and respiration) of 2 bacterial isolates.

In order to test the direct effect of $p \mathrm{CO}_{2}$ on bacterioplankton, it is essential to isolate them from the rest of the microbial food web components. The best approach is working with isolates or strains that are abundant and/or relevant in the ocean and that are likely to respond in a different way to a similar stress. We selected different bacterial isolates representative of 2 important families in marine surface waters: Rhodobacteraceae (MED165) and Flavobacteriaceae (MED217).

Rhodobacteraceae includes the Roseobacter lineage, which is adapted to use monomers, such as sugars or amino acids, and typically constitute about $20 \%$ of the bacterial community in eutrophic coastal waters (Buchan et al. 2005, Alonso-Gutiérrez et al. 2009). On the other hand, members of the family Flavobacteriaceae are successful in the degradation of polymeric substances and are particularly abundant during decaying phytoplankton blooms (Pin- hassi et al. 2004, Alderkamp et al. 2006, Teira et al. 2008), possibly accounting for up to more than $50 \%$ of total bacterial abundance.

\section{MATERIALS AND METHODS}

\section{Bacterial cultures and experimental setup}

The 2 strains (MED165 and MED217) were isolated in May 2001 from the surface waters $(5 \mathrm{~m})$ of Blanes Bay (Mediterranean Sea) and were kindly provided by J. M. Gasol (ICM-CSIC). MED165 belongs to Rhodobacteraceae and is $99.8 \%$ similar to Roseobacter sp. AY576690; whereas MED217 belongs to Flavobacteriaceae and is $99.6 \%$ similar to Cytophaga sp. AY745817. Both MED165 and MED217 were isolated from 1:20 seawater dilution cultures enriched with inorganic phosphorus. Hereafter we refer to these isolates as Roseobacter (MED165) and Cytophaga (MED217).

The strains were initially grown in Zobell liquid medium (4 $\mathrm{g}$ of peptone $\left[\right.$ Bacto $^{\mathrm{TM}}$ Peptone; Difco 211677] and $0.8 \mathrm{~g}$ of yeast extract [Bacto Yeast Extract; Difco 212750] dissolved in $600 \mathrm{ml}$ of $0.2 \mu \mathrm{m}$ filtered seawater and $200 \mathrm{ml}$ of sterile MQ water) for $1 \mathrm{wk}$. Thereafter, they were grown in $0.2 \mu \mathrm{m}$ filtered seawater amended with $0.5 \mathrm{ml}$ of Zobell medium per litre of seawater in 21 glass culture flasks.

In order to determine the periodicity of dilution for establishing a semi-continuous culture, we first studied the growth characteristics of each strain in the diluted media used (Fig. 1). Both strains approached the stationary phase after $28 \mathrm{~h}$; therefore, $80 \%$ dilutions were done every $24 \mathrm{~h}$. The derived growth rate, calculated using a logistic model, was slightly higher for Roseobacter than for Cytophaga, with doubling times of 4.1 and $5.3 \mathrm{~h}$, respectively.

Semi-continuous cultures $(\mathrm{n}=4)$ for each strain were simultaneously maintained by daily $80 \%$ dilutions with fresh medium. Culture flasks were kept in an incubation chamber at $18^{\circ} \mathrm{C}$ under $16 \mathrm{~h}$ light: $8 \mathrm{~h}$ dark cycles. Light was provided by cool white fluorescent tubes and irradiance, measured in air in a position close to the centre of the culture flasks, was $250 \mu \mathrm{mol}$ photons $\mathrm{m}^{-2} \mathrm{~s}^{-1}$. The cultures were allowed to acclimate to the experimental conditions by continuously bubbling with the target $\mathrm{CO}_{2}$ levels for $5 \mathrm{~d}$ under the light and temperature conditions previously described. To ensure sterile conditions mixed gases were supplied after filtering through a $0.2 \mu \mathrm{m}$ membrane filter. The $p \mathrm{CO}_{2}$ of fresh medium used for daily dilutions was also adjusted to the experimental 

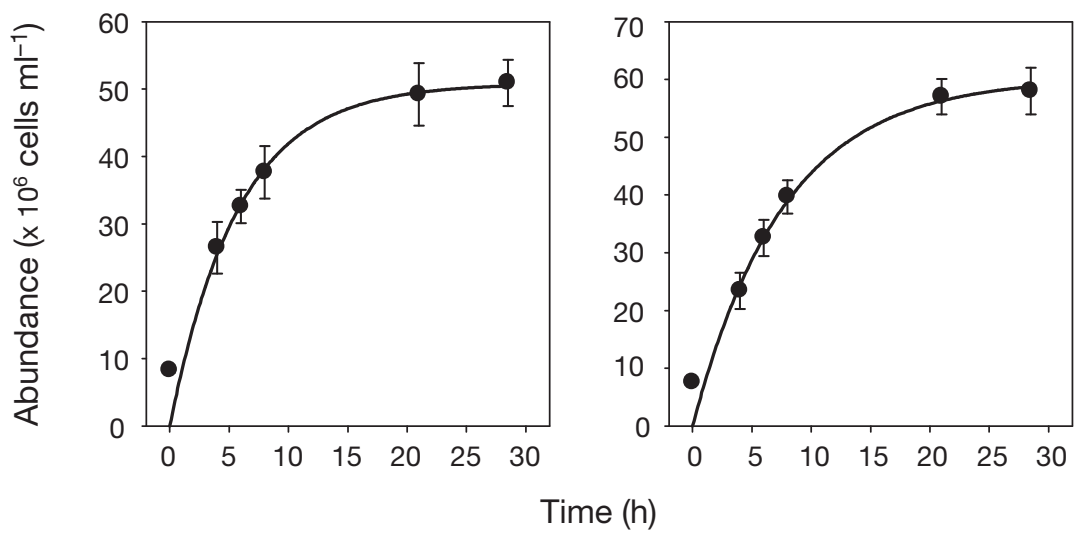

Fig. 1. Growth of (A) Roseobacter (MED165) and (B) Cytophaga (MED217) cultures in Zobell medium under light-dark cycles. Error bars represent \pm SE of microscope cell counts $(n=20)$

conditions. Cultures were aerated with air pumped from an open area outside the building, for the samples incubated under regular atmospheric $\mathrm{CO}_{2}$ levels (Ambient $\left.\mathrm{CO}_{2}: 380 \mathrm{ppmv}\right)(\mathrm{n}=2)$, and with a mix of air and $\mathrm{CO}_{2}$ from a 2000 to 3000 ppmv $\mathrm{CO}_{2}$ gas tank (Air Liquide), for the samples incubated under elevated $\mathrm{CO}_{2}$ levels (Elevated $\mathrm{CO}_{2}: 1000$ ppmv final concentration) $(\mathrm{n}=2)$. The mixture air: $\mathrm{CO}_{2}$ reaching the cultures was controlled by a double tube flow meter, and the flow in each flask was regulated by individual flow meters (Aalborg). After the acclimation period, a single sample was taken at 09:00 h (approx. $12 \mathrm{~h}$ after dilution). Sampling was carried out by siphonation using the flow generated after sucking out the air with a syringe connected via silicon tube to a glass tube inserted in each flask. Samples were taken for the estimation of inorganic and organic carbon system variables and fluorescence of coloured organic matter, as well as for bacterial abundance and activity (leucine incorporation, $\mathrm{CO}_{2}$ fixation and respiration rates).

\section{Dissolved inorganic carbon and $p \mathrm{CO}_{2}$}

Water samples $(\mathrm{n}=3$ ) for the analysis of dissolved inorganic carbon (DIC) in each flask were collected in $5 \mathrm{ml}$ glass serum vials and analysed with a NonDispersive Infrared Gas Analyzer (LiCOR 7000) within a few hours after collection. The system was standardised with $\mathrm{Na}_{2} \mathrm{CO}_{3}$ solutions. $\mathrm{pH}$ and temperature were measured with a Crison pH 25 pH meter and salinity with a Pioneer thermosalinometer Pioneer 30. The $\mathrm{pH}$ meter was calibrated to the total hydrogen ion concentration $\mathrm{pH}$ scale with a 2-amino2-hydroxymethyl-1,3-propanediol (tris) buffer prepared in synthetic seawater (DOE 1994). The $p \mathrm{CO}_{2}$ in the water samples was calculated from salinity, temperature, $\mathrm{pH}$, and DIC measurements using the inorganic carbon equilibrium constants from Merh- bach et al. (1973) as refit by Dickson \& Millero (1987), the boric acid constant from Dickson (1990), the ionic product of water from Millero (1995), and the dissociation constant of bisulfate ion from Dickson (1990).

\section{Fluorescence of particulate and dissolved organic matter (DOM)}

Samples for dissolved organic carbon (DOC) and fluorescence of coloured dissolved organic matter (FDOM) quantification were collected in $250 \mathrm{ml}$ acidcleaned Winkler flasks and filtered through acidrinsed $0.2 \mu \mathrm{m}$ filters (Pall Supor membrane disc) in an acid-cleaned, all-glass filtration system under low $\mathrm{N}_{2}$ flow pressure within $1 \mathrm{~h}$ of collection. Aliquots for the analysis of DOC were drawn into pre-combusted $\left(450^{\circ} \mathrm{C}, 12 \mathrm{~h}\right) 10 \mathrm{ml}$ glass ampoules, acidified with $25 \% \mathrm{H}_{3} \mathrm{PO}_{4}$ to $\mathrm{pH}<2$, heat sealed, and preserved at $4{ }^{\circ} \mathrm{C}$ until determination with a Shimadzu TOC-VCS analyzer under the principle of high temperature catalytic oxidation. The catalyser was $0.5 \% \mathrm{Pt}$ on $\mathrm{Al}_{2} \mathrm{O}_{3}$ balls. The DOC concentration of each sample was obtained by subtracting the average $( \pm$ SD) peak area of 3 to 5 injections $(150 \mu \mathrm{l})$ from the average $( \pm \mathrm{SD})$ peak area of the freshly produced Milli-Q water used as a blank and dividing by the slope of the standard curve with potassium hydrogen phthalate (ÁlvarezSalgado \& Miller 1998).

Aliquots for the quantification of FDOM were collected directly in a quartz cell of $1 \mathrm{~cm}$ path-length and measured in a Perkin Elmer LS 55 luminiscence spectrometer. The fluorescence of particulate organic matter (FPOM) was obtained by subtracting the FDOM from the fluorescence of the unfiltered sample. The Perkin Elmer LS 55 was equipped with a xenon discharge lamp, equivalent to $20 \mathrm{~kW}$ for $8 \mu \mathrm{s}$ duration. Discrete excitation/emission (Ex/Em) pair measurements were performed at Coble's (1996) 
peak-M, characteristic of marine humic-like substances (Ex/Em: $320 \mathrm{~nm} / 410 \mathrm{~nm}$ ) and peak-T, characteristic of protein-like substances (Ex/Em: $280 \mathrm{~nm} /$ $350 \mathrm{~nm})$. Four replicate measurements were performed for each Ex/Em pair. The system was calibrated with a mixed standard of quinine sulphate (QS) and tryptophan (Trp) in sulphuric acid $0.05 \mathrm{M}$ (Nieto-Cid et al. 2005). The equivalent concentration of every peak was determined by subtracting the average peak height from the corresponding Milli-Q water blank height and dividing by the slope of the standard curve. Fluorescence units were expressed in ppb equivalents of QS (ppb QS) for peak-M and ppb equivalents of Trp (ppb Trp) for peak-T. The precision was $\pm 0.1 \mathrm{ppb}$ QS and $\pm 0.6 \mathrm{ppb}$ Trp, respectively.

\section{Cell abundance and biovolume}

One or $2 \mathrm{ml}$ samples were fixed with $0.2 \mu \mathrm{m}$ filtered formaldehyde ( 1 to $2 \%$ final concentration) and subsequently stored at $4^{\circ} \mathrm{C}$ in the dark for 12 to $18 \mathrm{~h}$. Thereafter, each sample was filtered through a $0.2 \mu \mathrm{m}$ polycarbonate filter (Millipore, GTTP; $25 \mathrm{~mm}$ filter diameter) supported by a cellulose nitrate filter (Millipore, HAWP; $0.45 \mu \mathrm{m}$ ), washed twice with Milli-Q water, dried, and stored in a microfuge vial at $-20^{\circ} \mathrm{C}$. For total bacterial counts, cells were stained with a DAPI $\left(4^{\prime}, 6^{\prime}\right.$-diamidino-2-phenylindole) mix (5.5 parts of Citifluor [Citifluor], 1 part of Vectashield [Vector Laboratories] and 0.5 parts of PBS with DAPI [1 $\mu \mathrm{g} \mathrm{ml}^{-1}$ final concentration]). The slides were examined with an epifluorescence microscope equipped with a $100 \mathrm{~W} \mathrm{Hg-lamp} \mathrm{and} \mathrm{appropriate} \mathrm{filter} \mathrm{sets} \mathrm{for}$ DAPI. More than 200 DAPI-stained cells were counted per sample. Bacterial biovolumes were estimated from DAPI images as $(\pi / 4) W^{2}(L-W / 3)$, where $L$ is length, and $W$ is width. Although bacterial biovolume is commonly examined by using DAPI staining for DNA, it is important to note that DAPI images may underestimate cell sizes (Suzuki et al 1993).

\section{Catalysed reported deposition-fluorescence in situ hybridisation (CARD-FISH)}

In order to control potential cross-contamination of the cultures we used catalysed reported depositionfluorescence in situ hybridisation (CARD-FISH) with oligonucleotide probes specific for the Bacteroidetes group (CF319a) (Manz et al. 1996) and the Roseobacter lineage (Ros537). Filters for CARD-FISH were embedded in low-gelling-point agarose and incubated with lysozyme (Teira et al. 2008). Filters were cut in sections and hybridized for $2 \mathrm{~h}$ at $35^{\circ} \mathrm{C}$ with horseradish peroxidase (HRP)-labelled oligonucleotide probes. Tyramide-Alexa488 was used for signal amplification (20 min) as previously described (Pernthaler et al. 2002). We used 55\% formamide for both probes. Cells were finally counter-stained with a DAPI-mix. The slides were examined with an epifluorescence microscope equipped with a $100 \mathrm{~W}$ Hg-lamp and appropriate filter sets for DAPI and Alexa488. More than 200 DAPI-stained cells were counted per sample. For each microscope field, 2 different categories were enumerated: (1) total DAPIstained cells and (2) cells stained with the specific probe. The counting error, expressed as the percentage of standard error between replicates (SE/mean $\times$ 100 ), was $<2 \%$ for DAPI counts and $<10 \%$ for FISH counts.

The CARD-FISH using probes of the lineage Roseobacter (Ros537) and for the class Bacteroidetes (CF319a), indicated that problems of cross-contamination were negligible in the case of Roseobacter cultures (ca. $100 \%$ of the DAPI-stained cells hybridized with the Ros537 probe both in the High and in the Low $\mathrm{CO}_{2}$ treatments), whereas a minor crosscontamination with Roseobacter cells was detected in the Cytophaga cultures (ca. 90\% of the DAPIstained cells hybridized with the CF319a probe, and ca. $10 \%$ with the Ros537; both in the High and in the Low treatments) (data not shown).

\section{Leucine incorporation}

The $\left[{ }^{3} \mathrm{H}\right]$ leucine incorporation method, modified as described by Smith \& Azam (1992), was used to determine BP. Samples (4 replicates and 2 killed controls) were incubated for $40 \mathrm{~min}$ in the same incubation chamber as the cultures. The theoretical leucine to carbon conversion factor (CF) was used to calculate bacterial biomass production (BP) rates from Leu

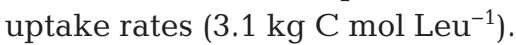

\section{$\mathrm{CO}_{2}$ fixation}

Eight $5 \mathrm{ml}$ acid-cleaned glass vials were filled with culture, inoculated with $180 \mathrm{kBq}(5 \mu \mathrm{Ci})$ of $\mathrm{NaH}^{14} \mathrm{CO}_{3}$ and then incubated for $1 \mathrm{~h}$ in a temperaturecontrolled photosynthetron incubator (CHPT). Each 2 replicates were exposed to a range of 4 irradiance levels $\left(0,100,250\right.$, and $1000 \mu \mathrm{mol}$ photons $\left.\mathrm{m}^{-2} \mathrm{~s}^{-1}\right)$ in 
order to assess the effect of light on bacterial $\mathrm{CO}_{2}$ fixation. After the incubation period, the samples were filtered at very low vacuum pressure $(<50 \mathrm{~mm} \mathrm{Hg})$ through $0.2 \mu \mathrm{m}$ polycarbonate filters using a system that allows the recovery of the filtrate. The filters and the filtrates were decontaminated by exposing them to fumes of concentrated $\mathrm{HCl}$ for $12 \mathrm{~h}$ and by adding $100 \mathrm{\mu l}$ of $50 \% \mathrm{HCl}$ and shaking for $12 \mathrm{~h}$, respectively. Two extra replicates were inoculated and immediately decontaminated (without incubation) in order to obtain a time zero value. A multipurpose liquid scintillation cocktail was used for both filters and filtrates (Insta-Gel plus, Perkin Elmer). Quenching corrections were made using an external standard. As no significant effect of irradiance was found, either for Roseobacter or for Cytophaga (ANOVA test, $\mathrm{p}>0.5$, $\mathrm{n}=16$ ), we averaged the disintegrations per minute (DPMs) of the 8 bottles and subtracted the mean DPMs of the time zero value for $\mathrm{CO}_{2}$ fixation calculations. The amount of ${ }^{14} \mathrm{C}$ fixed as particulate organic carbon $\left(\mathrm{P}-\mathrm{CO}_{2}\right.$ fix) and the amount of ${ }^{14} \mathrm{C}$ subsequently released from the cells to the dissolved fraction (D-CO $\mathrm{CO}_{2}$ fix) was obtained as the mean value in the filter and mean value in the filtrate, respectively.

\section{Respiration}

Oxygen consumption rates were determined by dark-bottle incubations. Six dark, 50 ml, gravimetrically calibrated, borosilicate bottles were carefully filled from each culture, using silicone tubing, overflowing $>100 \mathrm{ml}$. An initial set of 3 dark bottles was fixed immediately for initial oxygen concentration, the remainder being kept in the dark for 1 to $2 \mathrm{~h}$ in the same incubation chamber as the cultures. Dissolved oxygen concentration was measured through automated precision Winkler titration performed with a Metrohm 721 DMS Titrino, using a potentiometric end point detector as described in Serret et al. (1999). Bacterial respiration (BR) was converted into $\mathrm{C}$ units by using a respiration quotient (RQ) of 0.8 (Williams \& del Giorgio 2005).

\section{Statistical analysis}

Data were log or arcsin transformed to attain normality and homocedasticity (tested by KolmogorovSmirnov and Levene tests, respectively). The unpaired $t$-test was then used for comparisons of 2 datasets (Elevated vs. Ambient treatments). When homocedasticity failed, we used a $t$-test assuming unequal variances. An ANOVA test was used for comparison of more than 2 datasets. All statistical analyses were computed using SPSS statistics ver. 19.0 software. In order to correct for the small sample size $(\mathrm{n}=4)$, we applied the correction proposed by Good (1982), substituting p by $\mathrm{p} \sqrt{0.5}$.

\section{RESULTS}

\section{$\mathrm{CO}_{2}$ system variables}

At the beginning of the acclimation period, the $p \mathrm{CO}_{2}$ of the air bubbled into the cultures was adjusted to 1000 ppmv in the Elevated $\mathrm{CO}_{2}$ treatment and to $380 \mathrm{ppmv}$ in the Ambient $\mathrm{CO}_{2}$ treatment. Due to bacterial activity at the sampling time, i.e. $12 \mathrm{~h}$ after $80 \%$ dilution with acclimated fresh medium, the $p \mathrm{CO}_{2}$ of seawater in the Elevated $\mathrm{CO}_{2}$ treatment was $1162 \pm 84$ ppmv in the Roseobacter and $1137 \pm$ 51 ppmv in the Cytophaga cultures. By contrast, in the Ambient $\mathrm{CO}_{2}$ treatment, the seawater $p \mathrm{CO}_{2}$ was significantly ( $t$-test, $\mathrm{p}=0.047, \mathrm{n}=4$ ) higher in the Cytophaga cultures $(412 \pm 27$ ppmv) than in the Roseobacter cultures (242 $\pm 11 \mathrm{ppmv})$. The mean $\mathrm{pH}$ in the Elevated $\mathrm{CO}_{2}$ treatment was 7.60 in both cultures, whereas the $\mathrm{pH}$ in the Ambient $\mathrm{CO}_{2}$ treatment was significantly higher ( $t$-test, $\mathrm{p}=0.026, \mathrm{n}=4$ ) in Roseobacter (8.17 \pm 0.03$)$ than in Cytophaga cultures $(7.99 \pm 0.02)$.

\section{DOC and induced fluorescence of particulate and DOM}

DOC concentration at the sampling time was higher in the Roseobacter (372 $\pm 5 \mu \mathrm{mol} \mathrm{C} 1-^{1}$ ) than in the Cytophaga $\left(286 \pm 10 \mu \mathrm{mol} \mathrm{C} \mathrm{^{-1 } )}\right.$ cultures, and no significant differences were found between the Elevated and the Ambient $\mathrm{CO}_{2}$ treatments. The proteinlike fluorescence of particulate organic matter (FPOM-T) at the sampling time was higher in the Roseobacter than in the Cytophaga cultures (Fig. 2A). There were no significant differences between the mean FPOM-T in the Elevated and Ambient $\mathrm{CO}_{2}$ treatments. The protein-like fluorescence of dissolved organic matter (FDOM-T) followed a very similar pattern than the FPOM-T (Fig. 2B). By contrast, the humic-like fluorescence of dissolved organic matter (FDOM-M) in the Cytophaga culture was significantly higher ( $t$-test, $\mathrm{p}=$ 0.03, n = 4) in the Ambient than in the Elevated $\mathrm{CO}_{2}$ treatment (Fig. 2C). 

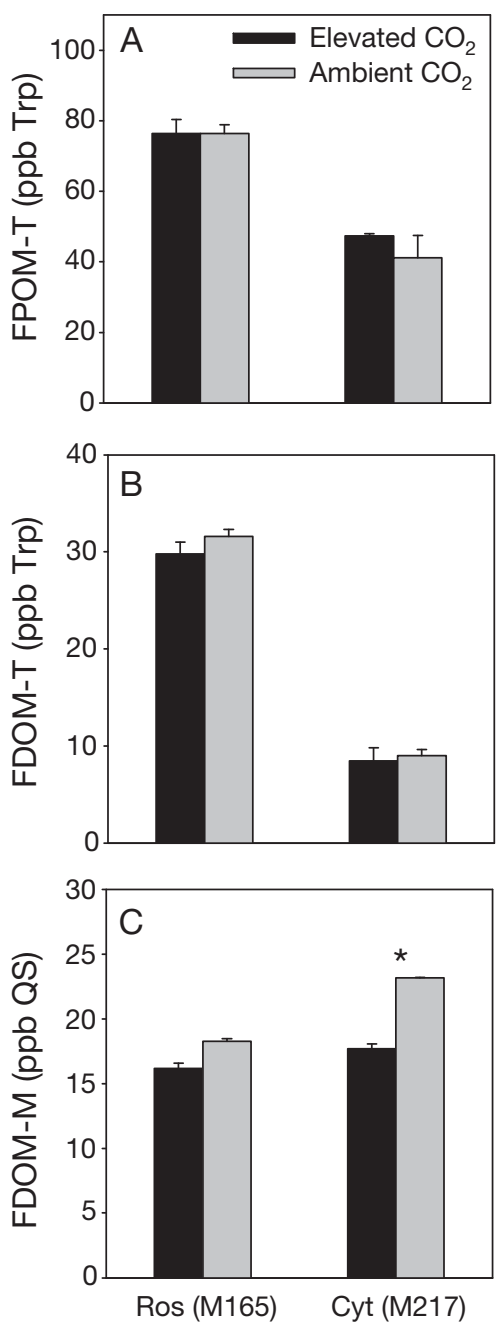

Fig. 2. (A) Protein-like fluorescence of particulate organic matter (FPOM-T), (B) protein-like fluorescence of dissolved organic matter (FDOM-T), and (C) humic-like fluorescence of the dissolved organic matter (FDOM-M) in the Roseobacter and Cytophaga cultures in the Elevated (black bars; $\mathrm{n}=$ 2) and Ambient (white bars; $\mathrm{n}=2$ ) $\mathrm{CO}_{2}$ treatments. Significant differences between the Elevated and Ambient $\mathrm{CO}_{2}$ treatments are marked with an asterisk $\left({ }^{\star} p<0.05\right)$

\section{Bacterial abundance and activity rates}

After the acclimation period, the abundance of $R o$ seobacter at the sampling time was ca. $50 \times 10^{6}$ cells $\mathrm{ml}^{-1}$, whereas that of Cytophaga was ca. $80 \times$ $10^{6}$ cells ml $^{-1}$ (Fig. 3A). There were no significant differences between the Elevated and the Ambient $\mathrm{CO}_{2}$ treatments. The mean biovolume of Roseobacter cells $\left(0.71 \pm 0.05 \mu^{3}\right)$ was higher than that of Cytophaga cells $\left(0.35 \pm 0.05 \mu^{3}\right)$, and no significant differences were found between the Elevated and Ambient $\mathrm{CO}_{2}$ treatments.
Despite lower cell abundance, rates of leucine incorporation BP were almost twice as high in the Roseobacter than in the Cytophaga culture (Fig. 3B). There were no significant differences between $\mathrm{CO}_{2}$ treatments. Similarly, anaplerotic $\mathrm{CO}_{2}$ fixation rates (both dissolved and particulate) were also higher in Roseobacter than in Cytophaga (Figs. 3C,D). There were no significant differences in the rates of $\mathrm{CO}_{2}$ fixation measured in the particulate fraction $\left(\mathrm{P}-\mathrm{CO}_{2}\right.$ fix; Fig. 3C) between treatments, whereas those measured in the dissolved fraction (D-CO $\mathrm{CO}_{2}$ fix) were significantly higher in the Elevated than in the Ambient $\mathrm{CO}_{2}$ treatment (Fig. 3D) in both isolates. Overall, P$\mathrm{CO}_{2}$ fixation represented 8 to $9 \%$ of the $\mathrm{BP}$ in both isolates.

On the other hand, BR was higher in the Cytophaga than in the Roseobacter cultures, particularly in the Ambient $\mathrm{CO}_{2}$ treatment (Fig. 3E). BR was significantly higher in the Ambient than in the Elevated $\mathrm{CO}_{2}$ treatment in the case of Cytophaga (t-test, $\mathrm{p}=$ $0.02, \mathrm{n}=4)$. The derived BGE, estimated as $\mathrm{BP} /(\mathrm{BP}+$ $\mathrm{BR})$, was higher for Roseobacter than for Cytophaga (Fig. 3F). Cytophaga showed a significantly (t-test, $\mathrm{p}=0.005, \mathrm{n}=4$ ) higher $\mathrm{BGE}$ in the Elevated $\mathrm{CO}_{2}$ $(0.57 \pm 0.01)$ than in the Ambient $\mathrm{CO}_{2}(0.49 \pm 0.02)$ treatment, while Roseobacter growth efficiency did not respond to the elevated $\mathrm{CO}_{2}$.

\section{DISCUSSION}

Both detrimental and stimulatory effects of seawater acidification associated with elevated $p \mathrm{CO}_{2}$ on marine plankton have been widely demonstrated at the organism level; including both phytoplankton and zooplankton species (see review by Riebesell et al. 2008). However, to the best of our knowledge, the effect of high $p \mathrm{CO}_{2}$ has been scantily tested on single marine heterotrophic bacteria species (Takeuchi et al. 1997, Labare et al. 2010). Moreover, none of these studies tested the effect of elevated $\mathrm{CO}_{2}$ on respiration or $\mathrm{CO}_{2}$ fixation rates. Both processes are relevant in terms of dissolved inorganic carbon system chemistry and carbon cycling, as $\mathrm{CO}_{2}$ fixation reduces, and respiration increases, the concentration of $\mathrm{CO}_{2}$ in seawater. The objective of our study was to evaluate the direct effect of elevated $p \mathrm{CO}_{2}$ levels on catabolic and anabolic processes rates of 2 relevant marine strains. Our results revealed that Roseobacter and Cytophaga strains, presumably carrying out contrasting functions in the ecosystem (Teira et al. 2008, 2009), responded differently to high $p \mathrm{CO}_{2}$. 

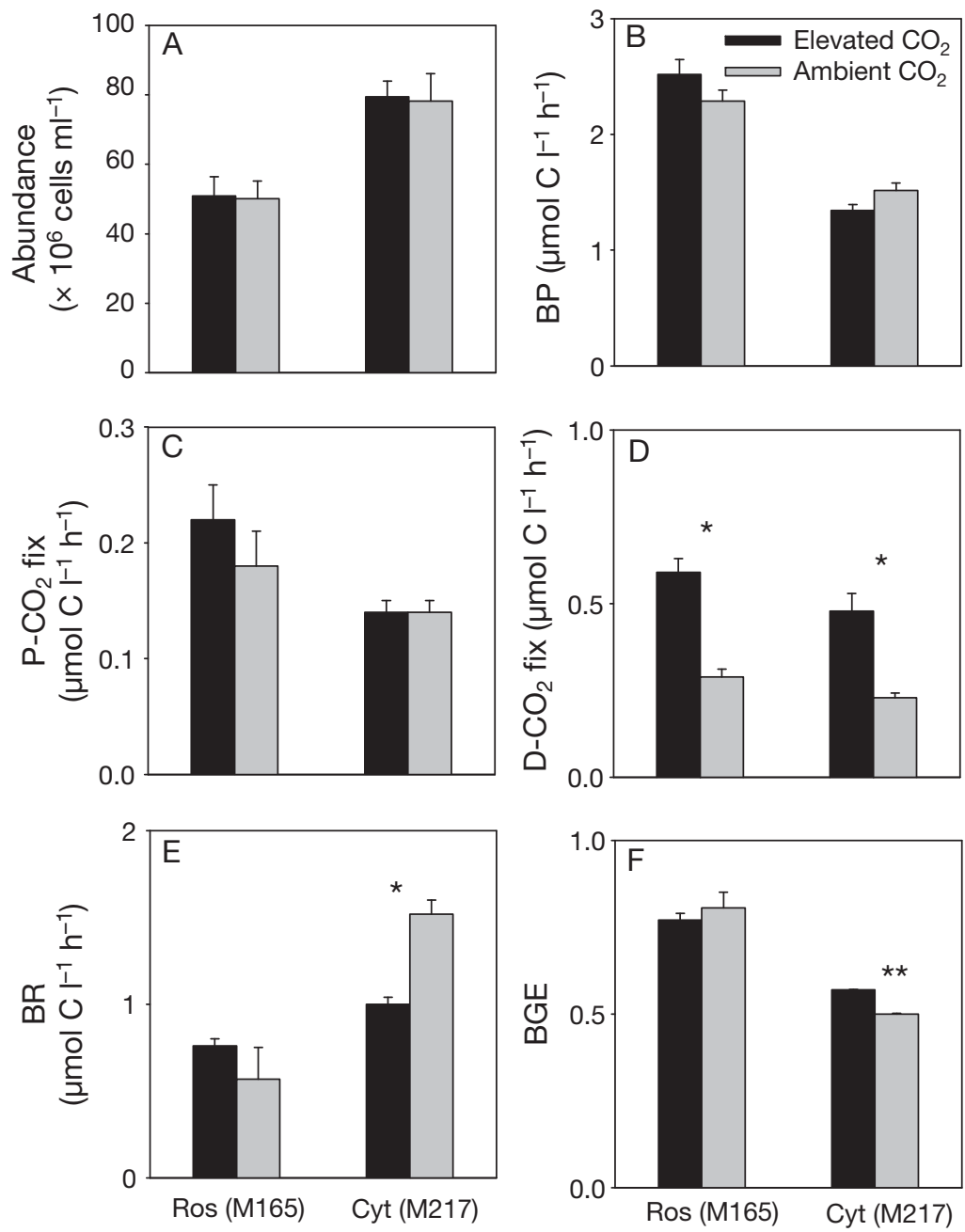

Fig. 3. (A) Bacterial abundance, (B) leucine incorporation rates (BP), (C) $\mathrm{CO}_{2}$ fixation measured in the particulate fraction $\left(\mathrm{P}-\mathrm{CO}_{2}\right.$ fix) rates, (D) $\mathrm{CO}_{2}$ fixation measured in the dissolved fraction $\left(\mathrm{D}-\mathrm{CO}_{2}\right.$ fix) rates, $(\mathrm{E})$ bacterial respiration (BR), and (F) bacterial growth efficiency (BGE) in Roseobacter and $C y$ tophaga cultures in the Elevated (black bars; $\mathrm{n}=2$ ) and Ambient (white bars; $\mathrm{n}=2) \mathrm{CO}_{2}$ treatments. Significant differences between the Elevated and Ambient $\mathrm{CO}_{2}$ treatments are marked with an asterisk $\left({ }^{*} \mathrm{p}<0.05 ;{ }^{* *} \mathrm{p}<0.01\right)$

also suggests higher bacterial biomass in the Roseobacter cultures.

Cell-specific BP rates in the Ambient $\mathrm{CO}_{2}$ treatment $(5.4$ and $13.1 \mathrm{fg} \mathrm{C}$ cell $^{-1} \mathrm{~d}^{-1}$ for Cytophaga and Roseobacter, respectively) are within the range of cell-specific BP rates measured in coastal waters where members of Rhodobacteraceae and Flavobacteriaceae are particularly abundant (Reinthaler \& Herndl 2005, Lamy et al. 2009, Lekunberri et al. 2010).

Heterotrophs can assimilate $\mathrm{CO}_{2}$ in various carboxylation reactions as part of central and peripheral pathways (Dijkhuizen \& Harder 1985). We found that $\mathrm{CO}_{2}$ fixation was independent of light in both strains, which points out to a purely heterotrophic assimilation process. The daily cellular rates of $\mathrm{P}$ $\mathrm{CO}_{2}$ fixation in the Ambient $\mathrm{CO}_{2}$ treatment by Roseobacter $(1.2 \mathrm{fg} \mathrm{C}$ cell $^{-1} \mathrm{~d}^{-1}$ ) and Cytophaga (0.43 fg C cell $^{-1} \mathrm{~d}^{-1}$ ) were about 1 order of magnitude higher than those reported by Alonso-Sáez et al. (2010) in arctic waters. The $\mathrm{P}-\mathrm{CO}_{2}$ fixation represented 7 to $8 \%$ of the total carbon anabolism, which agrees well with most previous estimates that suggest that 1 to $8 \%$ of the organic carbon in some heterotrophic bacteria can be attributed to $\mathrm{CO}_{2}$ assimilation in carboxylation reactions (Romanenko 1964, Doronia \& Trotsenko 1985, Roslev et al. 2004).

The higher $\mathrm{D}-\mathrm{CO}_{2}$ fixation and the lower respiration rates measured in Roseobacter compared to Cytophaga may explain the differences in $\mathrm{pH}$ and

\section{Roseobacter and Cytophaga metabolism under present-day $\mathrm{pCO}_{2}$ levels (380 ppmv)}

The bacterial yield in terms of cell abundance was lower for Roseobacter than for Cytophaga (50 vs. $80 \times$ $10^{6}$ cells $\mathrm{ml}^{-1}$ at the sampling time; Fig. 3A). The lower bacterial yield of Roseobacter contrasts with its higher $\mathrm{BP}$ and $\mathrm{P}-\mathrm{CO}_{2}$ fixation rates. A possible explanation could be a larger cell size of Roseobacter compared to Cytophaga. Based on microscope estimates, we found that the mean biovolume of Roseobacter cells was twice that of Cytophaga cells. The higher FPOM-T in Roseobacter than in Cytophaga cultures $p \mathrm{CO}_{2}$ observed in the Ambient $\mathrm{CO}_{2}$ treatment (8.17 in Roseobacter vs. 7.99 in Cytophaga), as $\mathrm{CO}_{2}$ fixation would tend to increase seawater $\mathrm{pH}$ and respiration would tend to decrease $\mathrm{pH}$.

\section{Roseobacter and Cytophaga metabolism under high $\mathrm{pCO}_{2}$ future levels (1000 ppmv)}

In the case of Roseobacter, the only significant response to elevated $p \mathrm{CO}_{2}$ was an increment in the rate of $\mathrm{D}-\mathrm{CO}_{2}$ fixation, a pattern also observed in Cytophaga. Although the effect of elevated $p \mathrm{CO}_{2}$ on 
the heterotrophic $\mathrm{CO}_{2}$ fixation has never been tested, an increase in photosynthetically produced-DOC release, as a consequence of high $p \mathrm{CO}_{2}$, has been previously observed in phytoplankton (e.g. Engel et al. 2004, 2005, Riebesell et al. 2007). Although the mechanism of $\mathrm{CO}_{2}$ fixation differs between phytoplankton and bacterioplankton, our results indicate that the fraction of recently fixed carbon released as DOM by heterotrophic bacteria could also increase under high seawater $p \mathrm{CO}_{2}$. By contrast, neither P$\mathrm{CO}_{2}$ fixation nor leucine incorporation (BP) were significantly affected by elevated $\mathrm{CO}_{2}$, which is also in accordance with there being no differences in cell abundance and biovolume. Several studies with natural microbial plankton populations, testing similar high $\mathrm{CO}_{2}$ levels, either failed to find a significant effect on bulk leucine incorporation rates (Allgaier et al. 2008) or did find an increase related to a higher DOC excretion by phytoplankton (Grossart et al. 2006).

Interestingly, a significant decrease in bacterial respiration occurred in the Elevated $\mathrm{CO}_{2}$ treatment in Cytophaga (Fig. 3E), which produced an increase in its growth efficiency under high $p \mathrm{CO}_{2}$ conditions (Fig. 3F). As far as we know, the effect of high $\mathrm{CO}_{2}$ on the growth efficiency of single marine bacterial species or natural bacterial communities has never been tested before (Liu et al. 2010). The higher respiration rates measured in the Ambient than in the Elevated $\mathrm{CO}_{2}$ treatment strongly concurs with the significantly higher concentration of humic substances observed in the Elevated $\mathrm{CO}_{2}$ treatment (Fig. 2C). Several studies have demonstrated the correlation between microbial respiration rates and rates of humic matter formation (Nieto-Cid et al. 2006, Lønborg et al. 2010). A decrease in respiration rates of soil bacteria with increasing $\mathrm{CO}_{2}$ concentration (0 to $1000 \mathrm{ppmv}$ ) was reported by Koizumi et al. (1991), although they did not provide an explanation for this metabolic response.

A decrease in phytoplankton respiration under high $p \mathrm{CO}_{2}$ conditions has been recently suggested by Hopkinson et al. (2010). These authors speculated that this respiration decline could be most likely related to a reduced energy cost on intracellular $\mathrm{pH}$ homeostasis. Most non-extremophilic bacteria grow over a broad range of external $\mathrm{pH}$ values, from 5.5. to 9.0, and maintain a cytoplasmatic $\mathrm{pH}$ within the narrow range of 7.4 to 7.8 (Booth 1985, Padan et al. 2005). Surface ocean bacteria grow in alkaline environments ( $\mathrm{pH} \sim 8.2$ ) and there is a large number of adaptive strategies for alkaline $\mathrm{pH}$ homeostasis (Padan et al. 2005), including increased metabolic acid production, increased ATP synthase that couples proton entry to ATP generation, changes in membrane properties, and increased expression and activity of monovalent cation/proton antiporters. Thus, energy savings when $\mathrm{pH}$ approaches the desired intracellular $\mathrm{pH}$ likely vary among different bacterial species, depending on the strategy for $\mathrm{pH}$ regulation. Unfortunately, we do not have information about the mechanisms implied in $\mathrm{pH}$ regulation in the studied strains. The lower external $\mathrm{pH}$ in the Elevated $\mathrm{CO}_{2}$ treatment $(\mathrm{pH}=7.60)$ could imply a reduced energy expense and thus, a higher growth efficiency and a lower total carbon demand, for the Cytophaga but not for the Roseobacter strain.

Our results contrast with recent observations of increases in bacterial polysaccharide degradation under $\mathrm{pH}$ lowered by 0.2 to 0.3 units, which has the potential to enhance respiratory $\mathrm{CO}_{2}$ production under high $\mathrm{pCO}_{2}$ future scenarios (Piontek et al. 2010). In the case of Cytophaga cultures, the implication of a reduced respiration under high $\mathrm{CO}_{2}$ concentration is a negative feedback to rising $\mathrm{CO}_{2}$. We have shown that laboratory experiments with cultured organisms may provide valuable information on physiological responses to the perturbation of $\mathrm{CO}_{2}$ concentrations. We have demonstrated here that some metabolic rates of 2 important representatives of marine bacteria do change in response to a higher $\mathrm{CO}_{2}$ concentration, and, contrary to some expectations, lowering $\mathrm{pH}$ did not negatively affect bacterial growth or even increased growth efficiency in the case of Cytophaga. In both cases, the bacterial activity under high $p \mathrm{CO}_{2}$ (higher $\mathrm{D}-\mathrm{CO}_{2}$ fixation or higher D-CO $\mathrm{C}_{2}$ fixation plus lower respiration rates) would increase the buffering capacity of seawater.

The complex interactions among microbial plankton organisms and different environmental factors imply that experiments under in situ conditions and with natural plankton communities are also essential to understand how the pelagic ecosystems will react to an increase in surface ocean $\mathrm{CO}_{2}$ concentration. Our results suggest the need for including simultaneous measurements of several key metabolic processes in $\mathrm{CO}_{2}$ perturbation experiments with natural microbial populations to better understand the net effect of human-induced rising seawater $\mathrm{CO}_{2}$. Moreover, we have shown that the response may vary among different bacteria taxa, and thus it is crucial to simultaneously analyze changes in bacterial function and taxonomic composition, as well as to conduct experiments over a wide range of different bacterial community structures. 
Acknowledgements. We thank Estación de Ciencias Mariñas de Toralla (ECIMAT) for the technical support during the experiments, and María Pérez Lorenzo for technical assistance. This research was supported by the Xunta de Galicia (grant 07MMA013103PR) and the MICINN contract DIFUNCAR (CTM2008-03790). E.T. was funded by a Ramón y Cajal contract from the Spanish Ministry of Science and Innovation. C.S was funded by an Isidro Parga Pondal contract from the Xunta de Galicia.

\section{LITERATURE CITED}

Alderkamp AC, Sintes E, Herndl GJ (2006) Abundance and activity of major groups of prokaryotic plankton in the coastal North Sea during spring and summer. Aquat Microb Ecol 45:237-246

Allgaier M, Riebesell U, Vogt M, Thyrhaug R, Grossart H (2008) Coupling of heterotrophic bacteria to phytoplankton bloom development at different $\mathrm{pCO}_{2}$ levels: a mesocosm study. Biogeosciences 5:1007-1022

> Alonso-Gutiérrez J, Lekunberri I, Teira E, Gasol JM, Figueras A, Novoa B (2009) Pronounced seasonality in bacterioplankton composition of the coastal upwelling system of 'Ría de Vigo', NW Spain. FEMS Microbiol Ecol 70:493-505

> Alonso-Sáez L, Galand P, Casamayor EO, Pedrós-Alió C, Bertilsson S (2010) High bicarbonate assimilation in the dark by arctic bacteria. ISME J 4:1581-1590

> Álvarez-Salgado XA, Miller AEJ (1998) Simultaneous determination of dissolved organic carbon and total dissolved nitrogen in seawater by high temperature catalytic oxidation: conditions for precise shipboard measurements. Mar Chem 62:325-333

Booth IR (1985) Regulation of cytoplasmatic pH in bacteria. Microbiol Rev 49:359-378

> Buchan A, González JM, Morán MA (2005) Overview of the marine Roseobacter lineage. Appl Environ Microbiol 71: 5665-5677

> Caldeira K, Wickett ME (2003) Anthropogenic carbon and ocean pH. Nature 425:365

> Coble PG (1996) Characterization of marine and terrestrial DOM in seawater using excitation-emission matrix spectroscopy. Mar Chem 51:325-346

> Coffin RB, Montgomery MT, Boyd TJ, Masutani SM (2004) Influences of ocean $\mathrm{CO}_{2}$ sequestration on bacterial production. Energy 29:1511-1520

del Giorgio PA, Williams PJleB (2005) The global significance of respiration in aquatic ecosystems from single cells to the biosphere. In: del Giorgio PA, Williams PJleB (eds) Respiration in aquatic ecosystems. Oxford University Press, Oxford, p 267-303

Dickson AG (1990) Thermodynamics of the dissociation of boric acid in synthetic sea water from 273.15 to $318.15 \mathrm{~K}$. Deep-Sea Res 37:755-766

Dickson AG, Millero FJ (1987) A comparison of the equilibrium constants for the dissociation of carbonic acid in seawater media. Deep-Sea Res 34:1733-1743

Dijkhuizen L, Harder W (1985) Microbial metabolism of carbon dioxide. In: Dalton H (ed) Comprehensive biotechnology, Vol 1. Pergamon Press, Oxford, p 409-423

DOE (1994) Handbook of methods for the analysis of the various parameters of the carbon dioxide system in sea water, ver. 2. In: Dickson AG, Goyet C (eds) ORNL/
CDIAC-74. Department of Energy. http://cdiac.ornl.gov/ oceans/DOE_94.pdf

Doronia NV, Trotsenko YA (1985) Levels of carbon dioxide assimilation in bacteria with different pathways of $\mathrm{C} 1$ metabolism. Mikrobiologiya 53:885-889

Engel A, Delille D, Jacquet S, Riebesell U, Rochelle-Newall E, Terbrugeen A, Zondervan I (2004) TEP and DOC production by Emiliania huxleyi exposed to different $\mathrm{CO}_{2}$ concentrations: a mesocosm experiment. Aquat Microb Ecol 34:93-104

Engel A, Zondervan I, Aerts K, Beaufort L, Benthien A, Chou L (2005) Testing the direct effect of $\mathrm{CO}_{2}$ concentration on a bloom of the coccolithophorid Emiliania huxleyi in mesocosm experiments. Limnol Oceanogr 50:493-507

Fabry VJ, Seibel BA, Feely RA, Orr JC (2008) Impacts of ocean acidification on marine fauna and ecosystem processes. ICES J Mar Sci 65:414-432

> Good IJ (1982) Standardized tail-area probabilities. J Statist Comput Simulation 16:65-66

- Grossart HP, Allgaier M, Passow U, Riebesell U (2006) Testing the effect of $\mathrm{CO}_{2}$ concentration on the dynamics of marine heterotrophic bacterioplankton. Limnol Oceanogr 51:1-11

Hendriks IE, Duarte CM, Álvarez M (2010) Vulnerability of marine biodiversity to ocean acidification: a metaanalysis. Estuar Coast Shelf Sci 86:157-164

> Hopkinson BM, Xu Y, Shi D, McGinn PJ, Morel FMM (2010) The effect of $\mathrm{CO}_{2}$ on the photosynthetic physiology of phytoplankton in the Gulf of Alaska. Limnol Oceanogr 55:2011-2024

Joint I, Doney SC, Karl DM (2011) Will ocean acidification affect marine microbes? ISME J 5:1-7

- Koizumi H, Nakadai T, Usami Y, Satoh M, Shiyomi M, Oikawa T (1991) Effect of carbon dioxide concentration on microbial respiration in soil. Ecol Res 6:227-232

Labare MP, Bays JT, Butkus MA, Snyder-Leiby T, Smith T, Goldstein A (2010) The effects of elevated carbon dioxide levels on a Vibrio sp. isolated from the deep-sea. Environ Sci Pollut Res Int 17:1009-1015

> Lamy D, Obernosterer I, Laghdass M, Artigas LF and others (2009) Temporal changes of major bacterial groups and bacterial heterotrophic activity during a Phaeocystis globosa bloom in the eastern English Channel. Aquat Microb Ecol 58:95-107

> Lekunberri I, Calvo-Diaz A, Teira E, Morán XAG and others (2010) Changes in bacterial activity and community composition caused by exposure to a simulated oil spill in microcosm and mesocosm experiments. Aquat Microb Ecol 59:169-183

> Liu J, Weinbauer MG, Maier C, Dai M, Gattuso JP (2010) Effect of ocean acidification on microbial diversity and on microbe-driven biogeochemistry and ecosystem functioning. Aquat Microb Ecol 61:291-305

Lønborg C, Álvarez-Salgado XA, Richardson K, MartínezGarcía S, Teira E (2010) Assessing the microbial bioavailability and degradation rate constants of dissolved organic matter by fluorescence spectroscopy in the coastal upwelling system of the Ría de Vigo. Mar Chem 119:121-129

> Manz W, Amann R, Ludwig W, Vancanneyt M, Schleifer KH (1996) Application of a suite of 16S rRNA-specific oligonucleotide probes designed to investigate bacteria of the phylum cytophaga-flavobacter-bacteroides in the natural environment. Microbiology (Read) 142: 1097-1106 
Merhbach C, Culberson CH, Hawley JE, Pytkowicz RM (1973) Measurement of the apparent dissociation constants of carbonic acid in seawater at atmospheric pressure. Limnol Oceanogr 18:897-907

Millero FJ (1995) Thermodynamics of the carbon dioxide system in the oceans. Geochim Cosmochim Acta 59: 661-677

Nieto-Cid M, Álvarez-Salgado XA, Gago J, Pérez FF (2005) DOM fluorescence, a tracer for biogeochemical processes in a coastal upwelling system (NW Iberian Peninsula). Mar Ecol Prog Ser 297:33-50

Nieto-Cid M, Álvarez-Salgado XA, Pérez FF (2006) Microbial and photochemical reactivity of fluorescent organic matter in a coastal upwelling system. Limnol Oceanogr 51:1391-1400

Padan E, Bibi E, Ito M, Krulwich TA (2005) Alkaline pH homeostasis in bacteria: new insights. Biochim Biophys Acta 1717:67-88

Pernthaler A, Pernthaler J, Amann R (2002) Fluorescence in situ hybridization and catalysed reporter deposition for the identification of marine bacteria. Appl Environ Microbiol 68:3094-3101

Pinhassi J, Sala MM, Havskum H, Peters F, Guadayol O, Malits A (2004) Changes in bacterioplankton composition under different phytoplankton regimens. Appl Environ Microbiol 70:6753-6766

Piontek J, Lunau M, Händel N, Borchard C, Wurst M, Engel A (2010) Acidification increases microbial polysaccharide degradation in the ocean. Biogeosciences 7 : 1615-1624

Raven J, Caldeira K, Elderfield H, Hoegh-Guldberg O, Liss P, Riebesell U (2005) Ocean acidification due to increasing atmospheric carbon dioxide. Royal Soc Policy Document 12/05, Clyvedon Press, Cardiff

Reinthaler T, Herndl GJ (2005) Seasonal dynamics of bacterial growth efficiencies in relation to phytoplankton in the southern North Sea. Aquat Microb Ecol 39:7-16

Riebesell U, Schulz KG, Bellerby RGJ, Botros M, Fritsche P, Meyerhöfer M (2007) Enhanced biological carbon consumption in a high $\mathrm{CO}_{2}$ ocean. Nature 450:545-548

Riebesell U, Bellerby RGJ, Grossart HP, Thingstad F (2008) Mesocosm $\mathrm{CO}_{2}$ perturbation studies: from organism to community level. Biogeosciences Discuss 5:641-659

Rochelle-Newall E, Delille B, Frankignoulle M, Gattuso JP, Jacquet S, Riebesell U (2004) Chromophoric dissolved organic matter in experimental mesocosms maintained

Editorial responsibility: Antonio M. Bode,

A Coruña, Spain under different $\mathrm{pCO}_{2}$ levels. Mar Ecol Prog Ser 272: 25-31

Romanenko VI (1964) Heterotrophic assimilation of $\mathrm{CO}_{2}$ by bacterial flora of water. Microbiologiya 33:610-614

Roslev P, Larsen MB, Jørgensen D, Hesselsoe M (2004) Use of heterotrophic $\mathrm{CO}_{2}$ assimilation as a measure of metabolic activity in planktonic and sessile bacteria. J Microbiol Methods 59:381-393

Royal Society (2005) Ocean acidification due to increasing atmospheric carbon dioxide. Royal Soc Policy Document 12/05, London

Sabine CL, Feely RA, Gruber N, Key RM, Lee K, Bullister JL (2004) The oceanic sink for anthropogenic $\mathrm{CO}_{2}$. Science 305:367-371

> Serret P, Fernández E, Sostres JA, Anadón R (1999) Seasonal compensation of microbial production and respiration in a temperate sea. Mar Ecol Prog Ser 187:43-57

Smith DC, Azam F (1992) A simple, economical method for measuring bacterial protein synthesis rates in seawater using 3H-leucine. Mar Microb Food Webs 6:107-114

Suzuki MT, Sherr EB, Sherr BF (1993) DAPI direct counting underestimates bacterial abundances and average cell size compared to AO direct counting. Limnol Oceanogr 38:1566-1570

Takeuchi K, Fujioka Y, Kawasaki Y, Shirayama Y (1997) Impacts of high concentration of $\mathrm{CO}_{2}$ on marine organisms; a modification of $\mathrm{CO}_{2}$ sequestration. Energy Convers Manage 38:S337-S341

Teira E, Gasol JM, Aranguren-Gassis M, Fernandez A, González J, Lekunberri I, Alvarez-Salgado XA (2008) Linkages between bacterioplankton community composition, heterotrophic carbon cycling and environmental conditions in a highly dynamic coastal ecosystem. Environ Microbiol 10:906-917

Teira E, Martínez-García S, Lønborg C, Álvarez-Salgado XA (2009) Growth rates of different phylogenetic bacterioplankton groups in a coastal upwelling system. Environ Microbiol Reports 1:545-554

Williams PJleB, del Giorgio PA (2005) Respiration in aquatic ecosystems: history and background. In: del Giorgio PA, Williams PJleB (eds) Respiration in aquatic ecosystems. Oxford University Press, Oxford, p 1-18

> Yamada N, Tsurushima N, Suzumura M (2010) Effects of seawater acidification by ocean $\mathrm{CO}_{2}$ sequestration on bathypelagic prokaryote activities. J Oceanogr 66: 571-580

Submitted: September 14, 2011; Accepted: February 3, 2012 Proofs received from author(s): April 24, 2012 